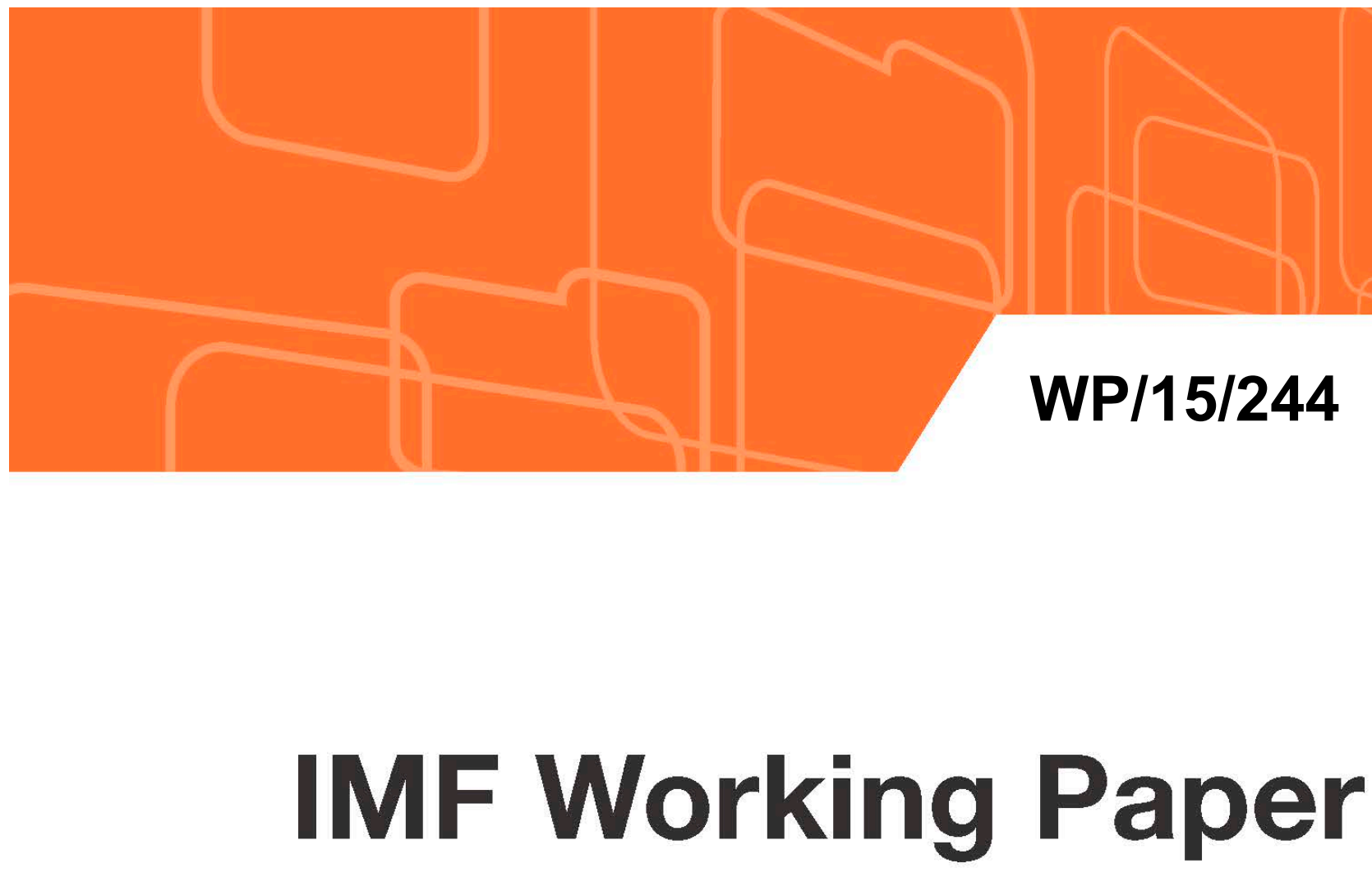

\title{
Functional Income Distribution and Its Role in Explaining Inequality
}

\author{
by Maura Francese and Carlos Mulas-Granados
}

IMF Working Papers describe research in progress by the author(s) and are published to elicit comments and to encourage debate. The views expressed in IMF Working Papers are those of the author(s) and do not necessarily represent the views of the IMF, its Executive Board, or IMF management.
I N
$N T E R$
N A T I O N A L
M O N E T A R Y
F U N D 


\title{
IMF Working Paper
}

Fiscal Affairs Department

\section{Functional Income Distribution and Its Role in Explaining Inequality ${ }^{1}$ \\ Prepared by Maura Francese and Carlos Mulas-Granados}

Authorized for distribution by David Coady

November 2015

\section{IMF Working Papers describe research in progress by the author(s) and are published to elicit comments and to encourage debate. The views expressed in IMF Working Papers are those of the author(s) and do not necessarily represent the views of the IMF, its Executive Board, or IMF management.}

\begin{abstract}
This paper is motivated by two parallel trends: the declining labor share of income and increasing inequality. Micro and macroeconomic data, covering up to 93 countries between 1970 and 2013, are used to assess whether the declining labor share of income has been a key factor driving growing inequality. The major conclusion is that changes in income inequality across a wide range of countries have been driven significantly by changes in the inequality of wages, while the distribution of income between labor and capital has not been a major factor.
\end{abstract}

JEL Classification Numbers: D31, D33, J3

Keywords: inequality, distribution, factor income distribution, wage share Authors’ E-Mail Addresses: mfrancese@imf.org; cmulasgranados@imf.org

\footnotetext{
${ }^{1}$ The authors wish to thank Andrea Brandolini, Benedict Clements, David Coady and Sanjeev Gupta for their helpful comments and suggestions. They are also grateful to all colleagues that have offered their comments and to participants at the Fiscal Affairs Department seminar and at the 17th Banca d'Italia Workshop on Public Finance (Perugia, April 9-11, 2015) for their valuable feedback. They are also grateful to Ryan Espiritu and Louis Sears who provided excellent research assistance.

A version of this paper appears as Chapter 6 in Inequality and Fiscal Policy, edited by Benedict Clements, Ruud de Mooij, Sanjeev Gupta, and Michael Keen (International Monetary Fund, 2015).
} 
Abstract

I. Introduction

II. Review of the Literature

III. Income Shares or the Distribution of Income? A Look at Household Data 8

IV. Labor Share and Inequality in a Macro Framework

V. Conclusion

Figures

1. Income Inequality and Wage Share in Group of Seven Countries 5

2. Average Marginal Impact on the Gini Index for Market Income of Changes in the Labor Share and Pseudo-Gini Indexes for Labor and Capital

3. Advanced and Emerging Economies: Marginal Impact on the Gini Index for Market

Income of Changes in the Labor Share and Pseudo-Gini Indexes for Labor and Capital

Tables

1. Decomposition of Changes in Inequality (Measured by the Gini Index)

2. Average effects on the Gini index for Market Income 13

3. Determinants of Income Inequality, Fixed Effects 15

4. Determinants of Income Inequality-Robustness Checks

5. Determinants of Wage Dispersion

Annexes

1. Gini Coefficients, Pseudo-Gini (or Concentration) Indexes, and Gini Correlations 20

2. Inequality Decomposition Using the LIS Data Set 23

3. Description of the Database

Annex Tables

2.1. Countries Included in the Analysis 24

3.1. Countries Considered in the Estimation and Descriptive Statistics for Inequality 


\section{INTRODUCTION}

In the years preceding the global economic and financial crisis, analysts and policymakers wondered about diverging trends between aggregate measures of economic performance (such as economic growth) and stagnating wages and household incomes. Public interest in the issue of whether capital was receiving too high a share of the economic pie was also high. $^{2}$ In 2006 Ben Bernanke, the Chairman of the Federal Reserve, expressed the hope that "corporations would use some of those profit margins to meet demands from workers for higher wages," and in 2007 Germany's finance minister asked European companies to "give a fairer share of their soaring profits." ${ }^{3}$ Interest in these contrasting trends has deepened since the onset of the financial crisis, driven in part by the rescue of financial institutions by many governments juxtaposed with rising unemployment and inequality. ${ }^{4}$

A brief examination of the time series of income inequality (measured by the Gini index) and the labor share of income ${ }^{5}$ in Group of Seven countries shows that the wage share has indeed been declining since the 1970s while inequality has been on the rise (Figure 1). On average, the wage share declined by 12 percent whereas income inequality increased by 25 percent in some advanced economies in barely three decades.

Although apparently correlated, these two phenomena may not be directly linked. Income inequality refers to the personal distribution of income, and the labor share refers to the remuneration of employees in total factor income (value added) in a given year. The classical economists of the nineteenth century took for granted that capitalists were rich and their income was solely based on the returns to capital, while laborers were poor and relied only on wages. As the world evolved during the twentieth century, scholars working in this field acknowledged that the study of factor shares and inequality became more difficult as evidence started to show mixed realities in which "many employees earn more than capitalists, many property owners work and many workers own property" (Lydall 1968, 2).

The analysis in this paper tests whether the declining labor share of income has been a key driving factor for the growth in inequality. The conclusion is that it has not - the most important determinant of rising income inequality has been the growing dispersion of wages, especially at the top of the wage distribution. This finding echoes the results of Piketty

\footnotetext{
${ }^{2}$ In this paper, capital income includes both profits and rents, that is, all value added that does not accrue to labor (including self-employment).

${ }^{3}$ See Glyn (2009) citing Bernanke's statement reported by the New York Times (July 20, 2006) and Germany's finance minister's declaration reported by the Financial Times (February 28, 2007).

${ }^{4}$ The flurry of ensuing policy work and analysis even caught on at Wall Street companies like Standard and Poor's and Morgan Stanley, which released their first reports on inequality in the fall of 2014 (Rotondaro 2014).

${ }^{5}$ For the rest of the paper, "labor share" of income and "wage share" of income are used as synonyms.
} 
(2014), who concludes that inequality of total income is closer to inequality of income from labor.

\section{Figure 1. Income Inequality and Wage Share in Group of Seven Countries}
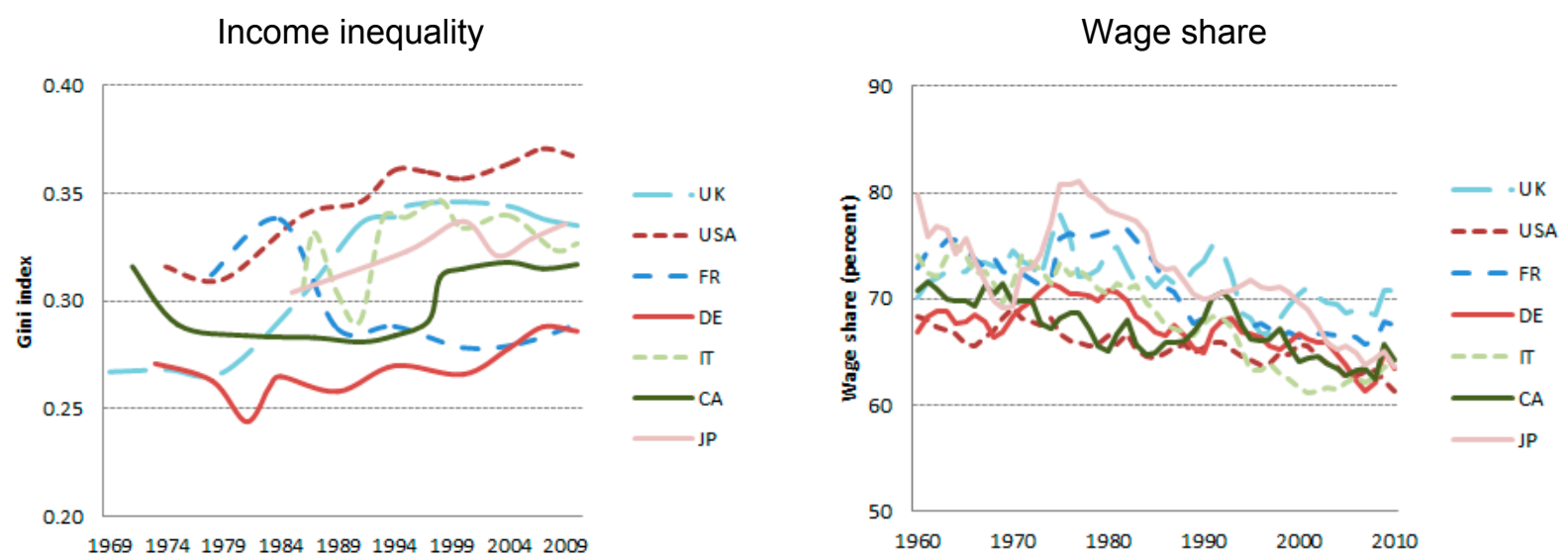

Sources: Luxembourg Income Study for Canada, France, Germany, Italy, United Kingdom, and United States, and Organisation for Economic Co-operation and Development for Japan (panel 1). For the years in which the Gini coefficient is available both from the OECD and LIS, data are in line and show similar patterns; European Commission AMECO database (panel 2).

Although these results confirm previous findings in the literature, the paper makes an important contribution by providing evidence from a wide sample of countries and simultaneously analyzing microeconomic data from household surveys and macroeconomic data from national accounts. As is well known, micro and macro data do not always perfectly match. However, this paper finds that they reveal broadly similar trends.

The remainder of the paper is organized as follows: the next section briefly reviews the relevant literature. The subsequent section explains how the Gini index can be decomposed and linked to factor shares and pseudo-Gini indices of the income sources, and applies this decomposition to available micro data. The vast sample of income surveys made available to researchers by the Luxembourg Income Study (LIS) data center is used for this exercise. Using 231 household surveys covering 43 countries for the period 1978-2010, the marginal effects of changes in factor shares and in the dispersion of labor and capital on the Gini index for market income are computed. The next section broadens the scope of the analysis and uses macroeconomic data for a large set of 93 countries for the period 1970-2013 to explore the aggregate effect of the labor share on income inequality. The final section presents closing remarks and the main conclusions. 


\section{REVIEW OF THE LITERATURE}

The analysis of factor income shares was considered the principal problem of political economy by classical economists such as David Ricardo. Until the 1960s this topic was given great preeminence in economic textbooks and academic research. When Kaldor (1961) famously summarized the long-term properties of economic growth, he stated that the shares of national income received by labor and capital were roughly constant over long periods. The analysis of factor income shares was the subject of 90 percent of the papers presented at the conference of the International Economic Association in 1965 (Marchal and Ducros 1968; Glyn 2009). The dominant theme was that factor shares were important for the macroeconomic performance of economies because they are linked to the potential "profitsqueeze" problem, that is, real wages growing faster than productivity (Glyn and Sutcliffe 1972; Bruno and Sachs 1985; Eichengreen 2007).

Since the 1970s, however, the analysis of factor shares has no longer been at the center of economic debate, given their lack of volatility and reflecting the fact that "the division of income could be easily explained by a Cobb-Douglas production function" (Mankiw 2007, 55). Those concerned with personal income distribution emphasized that there was no direct (or mechanical) link with factor shares, and that differences in personal income were related to differences in educational attainment (Stigler 1965; Goldfarb and Leonard 2005). In addition, a broader share of the population was starting to enjoy some kind of capital income. As home ownership, financial assets holdings, and capital-funded pensions expanded in advanced economies, the division into (pure) workers receiving only wages and (pure) capitalists and landlords receiving only profits and rents became blurred, thus contributing to the decline in attention to this theme.

Interest in the analysis of factor shares returned in the early 2000s. Atkinson (2009) cites three reasons for this growing attention: first, the analysis of factor shares is useful for understanding the link between incomes at the macroeconomic level (national accounts) and incomes at the individual or household level; second, factor shares can potentially help explain inequality in personal income (at least partly, if certain types of income are mainly received by some type of economic agents); and last, they "address the concern of social justice with the fairness of different sources of income" (Atkinson 2009, 5).

Researchers returning to work in this area initially focused on explaining the shifts in the labor share (Bentolila and Saint Paul 2003), its gradual but constant decline (De Serres and others 2002; Gollin 2002), and the relationship between wages and productivity (DewBecker and Gordon 2005; Feldstein 2008). The perception that citizens were not fully enjoying the fruits of the long period of economic expansion of the late 1990s and early 2000s also attracted the attention of national policymakers and international organizations. The IMF $(2007,2014)$, the European Commission (2007), the Bank for International Settlements (Ellis and Smith 2007), and the Organisation for Economic Co-operation and 
Development (OECD) (2008) all published reports that documented the decline in the labor share of income and provided several explanations for this trend, mainly linked to the impact of globalization and technological change on labor skills, international capital mobility, and wage bargaining.

Since then, contributions in this field can be divided into two groups: a collection of papers that document the recent and constant decline in the labor share and seek to explain the main drivers of this decline; and another group of studies that focuses more on its consequences for economic inequality. In the first group, most researchers use survey data and focus on single countries, mainly the United States (Gomme and Rupert 2004; Harris and Sammartino 2011; Elsby, Hobjin, and Sahin 2013); others have analyzed macroeconomic data and crosscountry developments (ILO 2011, 2012). In particular, the International Labour Organization (ILO) contributions have highlighted the impact of capital mobility on the evolution of factor shares since 2000. Stockhammer's (2013) report, published by the ILO, finds a strong negative effect of financial liberalization on the wage share and documents the consequences of cutbacks in welfare payments and globalization. The available evidence on the effects of technological change on labor income shares is mixed (positive in developing economies and modestly negative in advanced ones). Karabarbounis and Neiman (2014) attribute the declining share of labor income to the decrease in the relative price of investment goods, often ascribed to advances in information technology and the computer age, which have induced firms to shift away from labor and toward capital. According to these authors "the lower price of investment goods explains roughly half of the observed decline in the labor share, even when we allow for other mechanisms influencing factor shares, such as increasing profits, capital-augmenting technology growth, and the changing skill composition of the labor force" (Karabarbounis and Neiman 2014, 61).

In the second group of studies, which mostly focus on the interplay between functional income distribution and income inequality, researchers have also worked with survey household data from single countries. Adler and Schmid (2012) find that declining labor income shares are associated with growing inequality and an increasing concentration of market income in Germany. Similarly, Jacobson and Occhino (2012a, 2012b) follow Lerman and Yitzhaki (1985) and decompose the Gini coefficient into the weighted average of the pseudo-Gini indices of labor and capital income, with the weights equal to the two income shares. Using household data for the United States, they confirm that the decline in the labor share made total income less evenly distributed and more concentrated at the top of the distribution, thus increasing income inequality in the United States. According to their results, a 1 percent decrease in the labor share of income increases the Gini coefficient in the United States by $0.15-0.33$ percent. An ILO report addresses the relationship between wages and inequality using several sources, and it comes to the conclusion that "inequality starts in the labor market" (ILO 2015, xvii), meaning that developments in the distribution of wages have been key factors for inequality dynamics. 
In this context, the major contribution of this paper is that it performs a deeper empirical analysis than previous studies by using more micro and macro data sources and pooling them across a larger set of countries.

\section{INCOME SHARES OR THE DiSTRIBUTION OF INCOME? A LOOK AT HOUSEHOLd DATA}

This section explores how changes in labor and capital income shares and their distribution have affected the dynamics of income inequality. The inequality measure is the Gini index, and the data source is the Luxembourg Income Study (LIS) database. We use the Gini index because it is the most widely income inequality measure used both in the literature and in policy analysis. A wide set of household surveys covering a large sample of economies and spanning more than three decades is used. Thus, regularities that are supported by a broad empirical base can be sought.

The starting point is a decomposition of the Gini index that can then be applied to micro data. The decomposition analysis follows an established path in the literature (Lerman and Yitzhaki 1985; CBO 2011) and breaks down changes in the Gini index into changes in the income components and variations in their pseudo-Gini (or concentration) indices. In particular, assuming that household income $(y)$ comes from $K$ sources, the following relationship applies (see Annex 1 for details on how the decomposition is obtained):

$$
G_{y}=\sum_{k=1}^{K} C_{y_{k}} s_{k} .
$$

$G_{y}$ is the Gini index for total income $y$, and $C_{y_{k}}$ and $S_{k}$ are, respectively, the pseudo-Gini (or concentration) indices and the shares of each income component (given that $y=\sum_{k=1}^{K} y_{k}$ ).

Pseudo-Gini indices capture the level of "unevenness"/inequality of the distribution of each income component and are proportional to the Gini index of the income category ( $\left.C_{y_{k}}=\rho_{k}^{\text {Gini }} G_{y_{k}}\right) \cdot{ }^{6}$ As equation (1) indicates, the Gini index can therefore be represented as a weighted average of the pseudo-Gini indices of income components, where the weights are the income shares.

Changes in the overall Gini index occurring over a period starting at time $t_{0}$ can therefore be summarized as follows:

\footnotetext{
${ }^{6}$ See Annex 1 for a discussion of the relationship between Gini and pseudo-Gini indices and its interpretation.
} 


$$
\Delta G_{y}=\underbrace{\sum_{k=1}^{K} \Delta s_{k} C_{y_{k}}^{0}}_{\begin{array}{c}
\text { impact of changes } \\
\text { in the income shares }
\end{array}}+\underbrace{\sum_{k=1}^{K} \Delta C_{y_{k}} s_{k}^{0}}_{\begin{array}{c}
\text { impact of changes } \\
\text { in the concentration } \\
\text { of the income components }
\end{array}}+\underbrace{\sum_{k=1}^{K} \Delta s_{k} \Delta C_{y_{k}}}_{\approx 0},
$$

in which the third addend is likely close to zero (both income shares and inequality tend to move slowly over time).

Given equation (1), it is also possible to recover the marginal impact of changes in pseudoGini indices:

$$
\frac{\delta G_{y}}{\delta C_{y_{k}}}=s_{k} .
$$

As to the impact of changes in the income shares, assuming that a variation in labor income $(l)$ is compensated for by an opposite change in capital income $(c)$, while everything else stays the same, gives the following:

$$
\frac{\delta G_{y}}{\delta s_{l}}=C_{l}-C_{c} .
$$

If the pseudo-Gini index of capital is higher than that of labor, an increase in the labor share reduces inequality (whereas a reduction raises the Gini index). This condition requires the Gini index for capital income to be "sufficiently" higher than that of labor. Empirical values for the decomposition of the Gini index are computed using the LIS database; Annex 2 presents how the breakdown is computed.

The analysis begins by considering a small sample of advanced economies: France, Germany, the United Kingdom, and the United States. These countries are the Group of Seven members with the highest and the lowest levels of income inequality (Figure 1, panel 1); in addition, longer series are available for these countries, allowing developments over an extended period to be considered, which is helpful given that inequality tends to move slowly.

Table 1 reports the results of decomposing the change in the Gini index (according to the breakdown described in equation (2)) observed in these countries since the late $1970 \mathrm{~s} .{ }^{7} \mathrm{We}$

\footnotetext{
${ }^{7}$ The results presented here are robust to using alternative decomposition measures to calculate the contribution of income components to overall inequality. See the discussion in Annex 1, and in particular footnote 27.
} 
start by considering disposable income $y^{\text {net }}$ (market income $m$ plus transfers $g^{8}$ and minus taxes $t$ ); the first row in the table shows that the increase in inequality has been significant: more than 25 percent and 35 percent, respectively, in the United States and the United Kingdom, and almost 10 percent in Germany. In France, inequality is lower than in the 1970s and mid-1980s, and has been substantially stable since the mid-1990s with a slight pickup in recent years. ${ }^{9}$ Looking at market income $m$, the increase in inequality (Table 1 , row 5 ) has been substantial for all four countries, and larger than that registered for disposable income. Transfers and taxes have contained the increase in inequality.

The main result of the decomposition exercise suggests that the driving factor behind growing inequality in market income has not been the decline in the labor share, but the increase in the pseudo-Gini indices, mainly that of labor income (Table 1, row 7). ${ }^{10}$ The increase in the pseudo-Gini for labor income accounts for 75 percent of the increase in market income inequality in Germany; more than 90 percent and 95 percent in the United States and the United Kingdom, respectively; and for 100 percent of the small increase observed in France. Changes in the labor share of income appear to have made a negligible contribution to the overall increase in inequality (Table 1 , row 6). ${ }^{11}$

Given the wealth of data offered by the LIS database, the empirical decomposition of the Gini index for market income can be extended to a larger sample of countries (43 in total) that includes not only advanced economies (26) but also emerging ones (17). Selecting as a starting year the oldest available income survey in each country since the late 1970s, the

\footnotetext{
${ }^{8}$ Gross income $y$ is defined as market income $m$ plus transfers $g$ (see Annex 2).

${ }^{9}$ The Gini index for disposable income for France published by the OECD, which covers the period 19962011, displays values close to those that can be computed using LIS data. For the most recent years, it shows that inequality has been slightly increasing in this country.

${ }^{10}$ These findings are in line with others available in the literature. For example, Hoeller and others (2012) also find that the main driver of market-income inequality is inequality in labor income.

${ }^{11}$ A comparison of these results with the CBO (2011) study on the United States shows that the overall picture is similar (for instance, the percentage increase in the Gini index for market income is similar: 23 percent vs. 21 percent) and both analyses suggest that the most relevant driving factor has been the rising unevenness of income sources. However, the contribution of shifting income composition is lower in this analysis based on the LIS data set. The CBO study finds that during the period 1979-2007, increases in the pseudo-Gini account for 80 percent of the total change in the Gini index for market income, the rest being due to the shift in income shares. If 2007 had been taken to be the final year in this paper's analysis, the contribution of changes in income shares would have been found to be negligible (in line with what is found using 2010 as an end point), while almost all the increase in inequality would be explained by growing income inequality (of which 90 percent can be ascribed to the dynamics in the distribution of labor income). This difference may reflect the definitions adopted in the two studies: whereas the CBO analysis excludes business income (such as income from businesses and farms operated by their owners) from labor income, this analysis using LIS data includes earnings of the self-employed in this category (Annex 2).
} 
analysis can be expanded to include a total of 231 income surveys covering the past three decades (Annex Table 2.1). ${ }^{12}$

Table 1. Decomposition of Changes in Inequality (Measured by the Gini Index)

\begin{tabular}{|c|c|c|c|c|}
\hline & US 1979-2013 & UK 1979-2010 & -2010 & -2010 \\
\hline$\Delta \mathrm{G}_{\text {ynet }}$ & 0.08 & 0.10 & 0.03 & -0.01 \\
\hline Impact of changes in taxation & 0.01 & 0.00 & -0.02 & 0.00 \\
\hline$\Delta \mathrm{Gy}$ & 0.07 & 0.10 & 0.05 & -0.01 \\
\hline Impact of changes in transfers & -0.03 & -0.03 & -0.03 & -0.03 \\
\hline$\Delta \mathrm{Gm}$ & 0.10 & 0.13 & 0.08 & 0.02 \\
\hline \multicolumn{5}{|l|}{ Impact of changes in income shares } \\
\hline labour $\quad \Delta \mathrm{s}_{1}\left(\mathrm{C}_{1}^{0}-\mathrm{C}_{\mathrm{c}}^{0}\right)$ & 0.00 & 0.00 & 0.01 & 0.00 \\
\hline \multicolumn{5}{|l|}{ Impact of changes in pseudo-Gini indexes } \\
\hline labour $\quad s^{0} \Delta C_{1}$ & 0.09 & 0.13 & 0.06 & 0.03 \\
\hline$s^{0}{ }_{c} \Delta C_{c}=-s^{0} \Delta C_{c}$ & 0.01 & 0.00 & 0.02 & 0.00 \\
\hline Residual & 0.00 & 0.00 & 0.00 & 0.00 \\
\hline $\mathrm{G}_{\text {ynet }}^{0}$ & 0.31 & 0.27 & 0.26 & 0.33 \\
\hline $\mathrm{G}_{\text {ynet }}$ in the final year & 0.40 & 0.36 & 0.29 & 0.31 \\
\hline $\mathrm{G}_{\mathrm{y}}^{0}$ & 0.36 & 0.30 & 0.29 & 0.34 \\
\hline $\mathrm{G}_{\mathrm{y}}$ in the final year & 0.43 & 0.40 & 0.34 & 0.33 \\
\hline $\mathrm{G}_{\mathrm{m}}^{0}$ & 0.41 & 0.39 & 0.42 & 0.44 \\
\hline$G_{m}$ in the final year & 0.51 & 0.52 & 0.49 & 0.47 \\
\hline $\mathrm{G}_{1}^{0}$ & 0.44 & 0.43 & 0.45 & 0.46 \\
\hline$G_{1}$ in the final year & 0.53 & 0.57 & 0.54 & 0.53 \\
\hline $\mathrm{G}_{\mathrm{c}}^{0}$ & 0.92 & 0.88 & 0.61 & 0.97 \\
\hline $\mathrm{G}_{\mathrm{c}}$ in the final year & 0.94 & 0.97 & 0.87 & 0.88 \\
\hline
\end{tabular}

Source: Authors calculations on LIS data. The decomposition of changes in market income inequality (lines 6 to 9 in the table) follows equation (18) in Annex 2. Annexes 1 and 2 detail the methodology used for the Gini index decomposition. The initial (denoted by 0 ) and final years vary by country.

Once the components of the Gini index are calculated, the average marginal effects of changes in the income composition and the pseudo-Gini indices for labor and capital can be calculated for each country. The results obtained from this extended sample mirror those described for France, Germany, the United Kingdom, and the United States. The main hypothesis is confirmed. The variable that has had the most sizable impact on market-income

\footnotetext{
${ }^{12}$ Household surveys over such a long period and covering a broad set of countries are obviously heterogeneous. Of course, pooling all the data would not be advisable. The analysis therefore proceeds by considering each survey separately (taking into account whether income and income components are recorded net or gross of taxes), then assessing the impact on inequality of the different factors for each country and finally across the entire sample.
} 
inequality (as measured by Gini coefficients) is the pseudo-Gini index of labor income; increased inequality of capital income also raise inequality, but by a much smaller degree given that wages represent the lion's share of market income for the vast majority of the surveyed households (see Figure 2 and Table 2, which report average marginal effects on inequality). Computed at sample average values, the analysis finds that a 10 percent increase in the pseudo-Gini index of labor income would increase the Gini index for market income by more than 9 percent.

Consistent with previous studies, the analysis finds that, on average, increases (reductions) in the wage share reduce (raise) the Gini index (because the pseudo-Gini index of capital is higher than that of labor). In this sample, however, this effect is small but statistically significant. For the average values observed in this sample, a 10 percent decline in the labor share would increase the inequality index of market income by about 0.9 percent. This result is mostly driven by emerging market economies, and is attributable to the larger difference between the pseudo-Gini index of capital and labor income relative to advanced economies. ${ }^{13}$ The overall magnitude and relevance of the marginal effects of changes in income shares and pseudo-Gini indices, however, are not very different in the two subsamples of countries (Figure 3).

\section{Figure 2. Average Marginal Impact on the Gini Index for Market Income of Changes in the Labor Share and Pseudo-Gini Indexes for Labor and Capital}

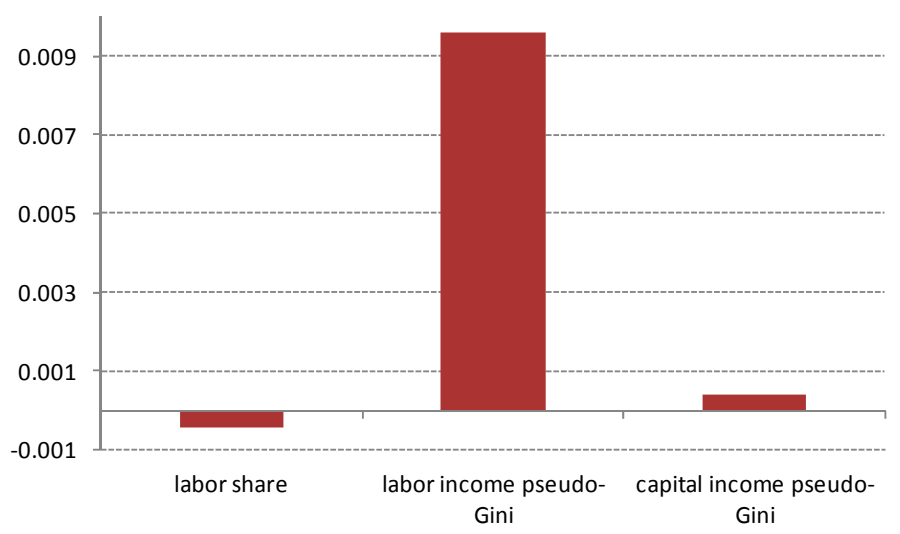

Source: Authors' calculation based on Luxembourg Income Study data.

Note: Average values across countries (43 countries; 231 observations or income surveys).

\footnotetext{
${ }^{13}$ The pseudo-Gini index for capital income in emerging economies is, on average, higher (by 0.16 ) than in advanced economies; the difference for labor income is less than half (0.07).
} 
Table 2. Average Effects on the Gini index for Market Income

\begin{tabular}{|c|c|c|c|c|}
\hline & All countries & St. Dev & $\mathrm{T}$ & $P>|t|$ \\
\hline \multicolumn{5}{|c|}{ Impact of a 0.01 change in the share of labor income } \\
\hline$\delta G_{m} / \delta s_{l}$ & $-0.0004 * *$ & 0.0012 & -2.2889 & 0.0272 \\
\hline \multicolumn{5}{|c|}{ impact of a 0.01 increase in the pseudo-Gini index } \\
\hline$\delta G_{m} / \delta C_{l}$ & $0.0096 * * *$ & 0.0003 & 250.3138 & 0.0000 \\
\hline$\delta G_{m} / \delta C_{c}$ & $0.0004 * * *$ & 0.0003 & 9.8787 & 0.0000 \\
\hline \multicolumn{5}{|c|}{$\begin{array}{l}\text { Significance levels are computed using standard deviations calculated over } \\
\text { the sample of } 43 \text { countries ( } 26 \text { advanced and } 17 \text { emerging) considering the } \\
\text { available income surveys since the late } 1970 \text { s. }\end{array}$} \\
\hline \multicolumn{5}{|c|}{ Significance level: * $10 \%, * * 5 \%, * * * 1 \%$} \\
\hline Subsamples & Advanced economies & Emerging ec & onomies & \\
\hline \multicolumn{5}{|c|}{ Impact of a 0.01 change in the share of labor income } \\
\hline$\delta G_{m} / \delta s_{1}$ & -0.0001 & -0.0010 & & \\
\hline \multicolumn{5}{|c|}{ impact of a 0.01 increase in the pseudo-Gini index } \\
\hline$\delta G_{m} / \delta C_{1}$ & 0.0096 & 0.0097 & & \\
\hline$\delta \mathrm{G}_{\mathrm{m}} / \delta \mathrm{C}_{\mathrm{c}}$ & 0.0004 & 0.0003 & & \\
\hline
\end{tabular}

Source: authors calculations on LIS data.

Figure 3. Advanced and Emerging Economies: Average Marginal Impact on the Gini Index for Market Income of Changes in the Labor Share and PseudoGini Indexes for Labor and Capital

\section{Advanced Economies}

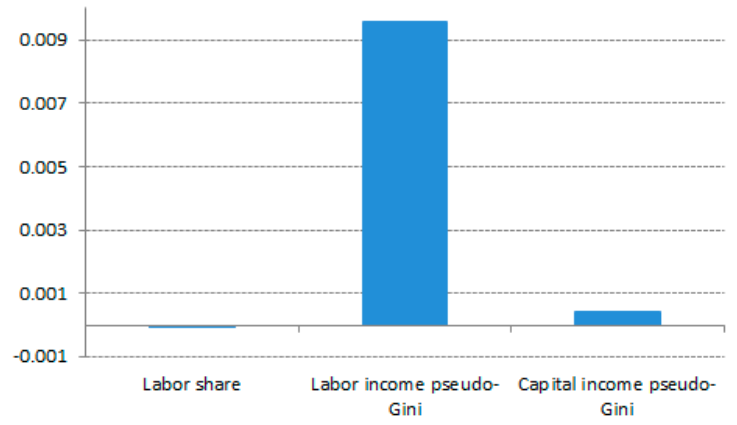

2. Emerging Economies

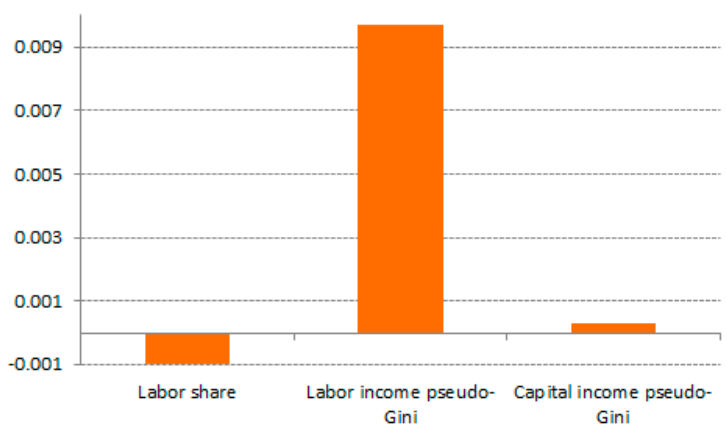

Source: Authors' calculations based on Luxembourg Income Study data.

Note: Average values across countries (panel 1: 26 countries; 174 observations or income surveys; panel 2: 17 countries; 57 observations or income surveys). 
A few remarks may also help qualify these findings and underscore some important aspects. The estimates obtained in the empirical exercise are affected by the weaknesses traditionally associated with income surveys, which generally underreport the extent of capital income; they also do not very accurately capture the tail of the income distribution (generally the exceptionally rich are poorly represented). This analysis therefore likely underestimates what has been happening at the top of the income scale and the relevance of developments concerning capital earnings (even though it should be recalled that the Gini index is more sensitive to changes in the middle of the distribution than in the tails). Recent work on the top 1 percent (or even smaller groups of very rich earners) would suggest that the share of income accruing to top earners has been increasing even more rapidly than that appropriated by other (less) rich percentiles (Alvaredo and others 2013). Even though these estimates may not appropriately incorporate these developments, they likely capture well the general trends.

\section{LAbor SHARE AND INEQUALITY IN A MACRO FrameWORK}

The goal of this section is to confirm using macro data and standard regression analysis of inequality the results of the previous section. This is a robustness check of whether the wage share has an effect on inequality (albeit small) and whether the distribution of labor income has a larger impact on the Gini index than the wage share.

The estimating equation is:

$$
G_{y^{\text {net }, i t}}=\alpha_{i}+\beta s_{l, i t}+\theta I_{l, i t}+\gamma r_{i t}+\omega x_{i t}+\varepsilon_{i t}
$$

in which $\varepsilon_{i t}$ is the error term, $i$ and $t$ are indices for country and time, and $r$ is the redistributive impact of the tax and welfare system (which is proxied by the ratio of public revenues to GDP, and social protection and health spending) ${ }^{14}$ It should be noted that government action may also have an indirect impact on inequality, via an effect on market income allocation. In the analysis presented here we do not aim at disentangling the direct and indirect effect, but to control for this factors when estimating the correlations between inequality and the wage share $\left(s_{l}\right)$ and inequality of labor income $\left(I_{l}\right) . x_{i t}$ are other control variables included in the regression.

The data set used in the empirical exercise (an unbalanced panel) covers a large sample of countries; the number of observations drops when control variables are added. ${ }^{15}$ The period covered is from the 1970s to 2013, although the coverage for each country varies (Annex

\footnotetext{
${ }^{14}$ The analysis on micro data (also reflecting data limitations for tax and transfers for the available sample of countries) allows the marginal effects on market-income inequality to be recovered. Here the Gini index for disposable income is used as a dependent variable because it is available for a wider set of countries.

15 The sample includes about 350 observations for the Gini equation (Table 3, columns 6 and 7). A factor that reduces the sample size is related to the Gini coefficient being available at less than an annual frequency.
} 
Table 3.1 reports the earliest and latest value for the Gini index for the countries included in the sample). The database and data sources are explained in detail in Annex 3. As to the estimation methodology, the Gini equation is initially explored using panel techniques. ${ }^{16}$

Table 3. Determinants of Income Inequality, Fixed Effects

\begin{tabular}{|c|c|c|c|c|c|c|c|}
\hline Gini Disposable Income & (1) & (2) & (3) & (4) & (5) & (6) & (7) \\
\hline Labor Share & $\begin{array}{c}-0.0008 * * * \\
(2.70)\end{array}$ & $\begin{array}{r}-0.0006 \\
(1.50)\end{array}$ & $\begin{array}{r}-0.0003 \\
(0.69)\end{array}$ & $\begin{array}{r}-0.0001 \\
(0.30)\end{array}$ & $\begin{array}{r}0.0000 \\
(0.02)\end{array}$ & $\begin{array}{r}0.0004 \\
(1.03)\end{array}$ & $\begin{array}{r}0.0006 \\
(1.21)\end{array}$ \\
\hline Dispersion of Labor income & & $\begin{array}{c}0.0242 * * * \\
(4.77)\end{array}$ & $\begin{array}{c}0.0203 * * * \\
(4.23)\end{array}$ & $\begin{array}{c}0.0174 * * * \\
(3.80)\end{array}$ & $\begin{array}{c}0.0173 * * * \\
(3.80)\end{array}$ & $\begin{array}{c}0.0173 * * * \\
(3.83)\end{array}$ & $\begin{array}{c}0.0161 * * * \\
(3.54)\end{array}$ \\
\hline Public Revenues & & & $\begin{array}{c}-0.0011 * * * \\
(3.40)\end{array}$ & $\begin{array}{c}-0.0008 * * \\
(2.28)\end{array}$ & $\begin{array}{c}-0.0007 * * \\
(2.19)\end{array}$ & $\begin{array}{c}-0.0008 * * \\
(2.39)\end{array}$ & $\begin{array}{c}-0.0008 * * \\
(2.29)\end{array}$ \\
\hline Public Social Protection Spending & & & & $\begin{array}{r}-0.0011 \\
(1.24)\end{array}$ & $\begin{array}{r}-0.0006 \\
(0.67)\end{array}$ & $\begin{array}{r}-0.0009 \\
(0.98)\end{array}$ & $\begin{array}{r}-0.0007 \\
(0.74)\end{array}$ \\
\hline Public Health Spending & & & & & $\begin{array}{c}-0.0046 * \\
(1.89)\end{array}$ & $\begin{array}{c}-0.0055 * * \\
(2.25)\end{array}$ & $\begin{array}{c}-0.0070 * * * \\
(2.67)\end{array}$ \\
\hline Economic Globalization & & & & & & $\begin{array}{c}0.0007^{* * *} \\
(2.80)\end{array}$ & \\
\hline Financial Globalization & & & & & & & $\begin{array}{c}0.0094^{* *} \\
(2.38)\end{array}$ \\
\hline Constant & $\begin{array}{l}0.3847 * * * \\
(25.89)\end{array}$ & $\begin{array}{l}0.3888 * * * \\
(22.28)\end{array}$ & $\begin{array}{l}0.4158 * * * \\
(19.26)\end{array}$ & $\begin{array}{l}0.4129 * * * \\
(19.32)\end{array}$ & $\begin{array}{l}0.4231 \text { *** } \\
(19.28)\end{array}$ & $\begin{array}{l}0.3650 * * * \\
(12.18)\end{array}$ & $\begin{array}{l}0.4051 * * * \\
(17.58)\end{array}$ \\
\hline Observations & 683 & 445 & 393 & 353 & 353 & 352 & 353 \\
\hline Number of Countries & 93 & 84 & 83 & 71 & 71 & 70 & 71 \\
\hline R-squared & 0.2817 & 0.4626 & 0.6363 & 0.6609 & 0.5810 & 0.3756 & 0.4252 \\
\hline
\end{tabular}

Absolute value of $t$ statistics in parentheses

* significant at $10 \% ;{ }^{* *}$ significant at $5 \% ; * *$ significant at $1 \%$

Results are reported in Table 3. The preferred specifications, the most complete ones, are reported in columns 6 and $7 .{ }^{17} \mathrm{With}$ regard to the relationship between the labor income share and the Gini index, the results indicate that inequality declines when the wage share increases (column 1); however, the estimated coefficient is significant only when the dispersion of labor income is not taken into account. When a proxy for the dispersion of wages (measured by the ratio of top 10 percent salaries to bottom 90 percent salaries) is added, the wage share seems to no longer matter (the coefficient is not significant), whereas the dispersion variable turns out to be positively (and significantly) related to inequality. ${ }^{18}$

\footnotetext{
${ }^{16}$ We run both a fixed and a random effects model. The Breusch and Pagan Lagrange multiplier test suggests that a fixed effects model is appropriate.

${ }^{17}$ The first columns of Table 3 report results of parsimonious specifications that were the starting point. Signs and significance of coefficients are robust when explanatory variables are added.

${ }^{18}$ Note that the variable that measures the ratio of the top 10 percent of salaries to the bottom 10 percent reported in Table 3 reflects total income dispersion. This choice guarantees a larger number of observations, which is consistent with the large data set of countries. The 10-to-90 income ratio of labor income (which
} 
With regard to the other control variables, all proxies aimed at capturing the redistributive impact of public policies have the expected negative effect on the Gini index (revenues and health spending display significant coefficients, but social protection spending does not) ${ }^{19}$ It is likely that also the quality, efficiency and design of public policies affects inequality. However, there are no widely available proxies or indicators that we could use in the empirical analysis to capture these effects, which in our panel framework are absorbed by country effects and not specifically singled out. In line with the literature, we include also a proxy for economic globalization. In the panel framework used other factors affecting inequality, which are not specifically accounted for, are absorbed by country effects (as the quality of public policies mentioned above).

The empirical methodology used in Table 3 is simple. It does not address the issue of the simultaneity between income inequality and the wage share. As a robustness check, we also estimate the Gini equation treating the wage share as an endogenous variable. Both panel instrumental variables and a full information maximum likelihood estimator are used. The latter considers the labor share as an observed endogenous variables in the Gini equation. ${ }^{20}$ When panel instrumental variables are used, the list of instruments includes the lagged value of the labor share, the lagged value of the unemployment rate, employment in the services sector and a proxy for the wage-bargaining framework. The instruments appear appropriate: while they are highly correlated with the instrumented variable, they are not correlated with the dependent variable (the Gini index). ${ }^{21}$

would directly capture wage dispersion) is only available for OECD countries. Nonetheless, both variables (that measured on total income and that measured on labor income) are highly correlated. Estimation results are the same when the model is run using the reduced sample of OECD countries and the 10-to-90 income ratio of labor income.

19 These results are robust to the inclusion of the unemployment rate as a control variable, as in Checchi and García-Peñalosa 2010. The inclusion of the unemployment rate in the Gini equation takes into account that labor income is nil for the unemployed. The model presented in Table 4 duly takes into account the impact of the unemployment rate as an instrument and/or explanatory variable for a wage share equation; for consistency, the same specification is maintained for both the fixed effects and other model estimations.

${ }^{20}$ The auxiliary equation for the wage share uses as explanatory variables the same variables used as instruments in the panel estimation: the lagged value of the labor share, the lagged value of the unemployment rate, employment in the services sector and a proxy for the wage-bargaining framework. We recognize that using the lagged wage share as a regressor in the wage share equation may result in biased estimated coefficients. But for the auxiliary equation we only aim at obtaining a good explanatory power.

${ }^{21}$ The R2 of the first step wage share equation is 0.86 , while the R2 of regressing the Gini index on the set of instruments is 0.01 . The wage share moves slowly, so it is reasonable that the lagged wage share is a good predetermined variable. Results are also in line with the expectation that the wage share is related to proxies for the characteristics of the labor market (such as the share of employed in the service sector, which is usually less unionized than industry, and the bargaining framework). This is also consistent with results obtained by Checchi and Garcìa-Peñalosa (2010). On a smaller sample of OECD economies, they study in detail the role of market institutions on personal income distribution, and conclude that greater unionization and wage bargaining are important factors. 
Table 4. Determinants of Income Inequality-Robustness Checks

\begin{tabular}{|c|c|c|c|}
\hline & $\begin{array}{l}\text { (1) Panel fixed } \\
\text { effects }\end{array}$ & $\begin{array}{l}\text { (2) Panel regression with } \\
\text { instrumental variables } \\
\text { (endogenous } \\
\text { variable=labor share) / } 1\end{array}$ & $\begin{array}{c}\text { (3) ML (with } \\
\text { endogenous labor } \\
\text { share in the Gini } \\
\text { equation) }\end{array}$ \\
\hline \multicolumn{4}{|l|}{ Gini Disposable Income } \\
\hline Labor Share & $\begin{array}{r}0.0004 \\
(1.03)\end{array}$ & $\begin{array}{r}-0.0003 \\
(0.37)\end{array}$ & $\begin{array}{c}-0.0015 * * * \\
(3.68)\end{array}$ \\
\hline Dispersion of Labor income & $\begin{array}{c}0.0173 * * * \\
(3.83)\end{array}$ & $\begin{array}{l}0.3226^{* * *} \\
(6.27)\end{array}$ & $\begin{array}{l}0.6036 * * * \\
(19.38)\end{array}$ \\
\hline Public Revenues & $\begin{array}{c}-0.0008^{* *} \\
(2.39)\end{array}$ & $\begin{array}{r}0.0000 \\
(0.05)\end{array}$ & $\begin{array}{c}-0.0014 * * * \\
(3.16)\end{array}$ \\
\hline Public Social Protection Spending & $\begin{array}{r}-0.0009 \\
(0.98)\end{array}$ & $\begin{array}{r}-0.0010 \\
(0.89)\end{array}$ & $\begin{array}{c}-0.0039 * \\
(1.76)\end{array}$ \\
\hline Public Health Spending & $\begin{array}{c}-0.0055^{* *} \\
(2.25)\end{array}$ & $\begin{array}{r}-0.0021 \\
(0.77)\end{array}$ & $\begin{array}{c}-0.0039 * \\
(1.78)\end{array}$ \\
\hline Economic Globalization & $\begin{array}{l}0.0007 * * * \\
(2.80)\end{array}$ & $\begin{array}{r}0.0007 \\
(1.87)\end{array}$ & $\begin{array}{c}0.0003 * \\
(1.61)\end{array}$ \\
\hline Constant & $\begin{array}{l}0.3650 * * * \\
(12.18)\end{array}$ & $\begin{array}{l}0.2698^{* * *} \\
(3.98)\end{array}$ & $\begin{array}{l}0.0459 * * * \\
(14.51)\end{array}$ \\
\hline Observations & 352 & 148 & 148 \\
\hline Number of Countries & 70 & 31 & \\
\hline R-squared & 0.3756 & 0.7813 & \\
\hline Chi 2 & & & 33.39 \\
\hline Prob $>$ Chi 2 & & & 0.0001 \\
\hline
\end{tabular}

Absolute value of $z$ statistics in parentheses

* significant at $10 \%$; ** significant at $5 \%$; *** significant at $1 \%$

/1 The list of instrumental variables include: the lagged value of the labor share, the lagged value of the unemployment rate, employment in the services sector and a proxy for the wage-bargaining framework.

Results (Table 4, columns (2) and (3)) of the robustness checks again suggest that the labor share has a negative but small effect on inequality, while inequality of labor income has a large and significant positive effect.

If the major conclusion that can be extracted from this empirical analysis is that higher income inequality is more driven by wage dispersion than by the wage share of national income, then the natural question becomes, what explains that dispersion? This issue is however not the major focus of this paper and could be a topic for further analysis. Without aiming at providing a comprehensive analysis, we include here (in Table 5) a simple regression that shows how some factors under the control of policy makers may be correlated with inequality of labor income. ${ }^{22}$ We recognize that this exercise is very simple and that a

\footnotetext{
${ }^{22}$ Again, this model was estimated using both versions of income dispersion (total and wage). Results reported in Table 5 are those from total dispersion to guarantee a larger sample. As noted in the previous footnote, these
} 
fully-fledged analysis would require more sophisticated tools. Column 5 shows that higher financial globalization and higher unemployment levels are associated with higher dispersion of wages. In contrast, higher unionization in industry, ${ }^{23}$ a higher share of educated workers, and higher primary government spending (as a proxy for the size of the state) are factors that help reduce the distance between higher and lower wages.

Table 5. Determinants of Wage Dispersion

\begin{tabular}{|c|c|c|c|c|c|}
\hline & (1) & (2) & (3) & (4) & (5) \\
\hline Financial Globalization & $\begin{array}{l}0.0719 * * \\
(2.07)\end{array}$ & $\begin{array}{l}0.0701 * \\
(1.69)\end{array}$ & $\begin{array}{l}0.037 * \\
(1.79)\end{array}$ & $\begin{array}{l}0.1531 * \\
(1.74)\end{array}$ & $\begin{array}{l}0.0788 * * * \\
(2.62)\end{array}$ \\
\hline Unemployment & & $\begin{array}{c}0.0082 * \\
(1.65)\end{array}$ & $\begin{array}{c}0.0066 * \\
(1.69)\end{array}$ & $\begin{array}{l}0.0231 * * \\
(2.05)\end{array}$ & $\begin{array}{l}0.0075 * * \\
(2.25)\end{array}$ \\
\hline Industry Unionization & & & $\begin{array}{c}-0.0118 * * * \\
(2.86)\end{array}$ & $\begin{array}{l}-0.024 * * * \\
(2.72)\end{array}$ & $\begin{array}{l}-0.01 * * * \\
(3.39)\end{array}$ \\
\hline Tertiary Education & & & & $\begin{array}{l}-0.018 * * * \\
(2.96)\end{array}$ & $\begin{array}{l}-0.009 * * * \\
(4.47)\end{array}$ \\
\hline Government Spending & & & & & $\begin{array}{l}-0.009 * * * \\
(5.22)\end{array}$ \\
\hline Constant & $\begin{array}{c}0.2295 * * \\
(9.73)\end{array}$ & $\begin{array}{c}0.1601 * * * \\
(2.89)\end{array}$ & $\begin{array}{c}0.5643 * * * \\
(3.72)\end{array}$ & $\begin{array}{c}1.0694 * * * \\
(3.31)\end{array}$ & $\begin{array}{c}0.8488 * * * \\
(6.86)\end{array}$ \\
\hline Observations & 1,045 & 810 & 785 & 405 & 342 \\
\hline Number of countries & 142 & 91 & 90 & 74 & 67 \\
\hline R-squared & 0.004 & 0.006 & 0.017 & 0.062 & 0.257 \\
\hline
\end{tabular}

\section{Conclusion}

This paper analyzes the relationship between functional and personal income distributions, a topic that has returned to center stage in the academic and policy discussion. In the advanced world the wage share and inequality have shown opposite trends in recent decades: the share of factor income to labor has been declining, while inequality has risen. This paper addresses this issue from different angles, first by analyzing what is behind widely used inequality measures based on micro data (that is, Gini indices), and second by running regression analyses on macro data to provide additional support to the main findings.

results are very similar when the model is estimated using a subsample of OECD countries and using wage dispersion.

${ }^{23}$ Jaumotte and Osorio Buitron (forthcoming) also find evidence that a decline in union density - the fraction of union members in the workforce-affects inequality, in particular, that it is associated with the rise of top income shares. 
The empirical evidence suggests that the most important determinant of income inequality is not the share of income that accrues to labor or capital, but the dispersion of labor income. This result reflects the fact that the lion's share of household income is labor earnings and its distribution has become more unequal. The increase in wage dispersion has been associated with growing financial globalization, a decrease in industry unionization, and a decline in the size of the state.

From a policy perspective these results suggest that to avoid unfavorable (or undesired) distributional consequences, policymakers will have to pay attention to labor market outcomes and to the dispersion of wages, including distortions induced in the labor market by different policy interventions or by changes in labor market institutions. ${ }^{24}$ Public policies that support inclusive growth (by, for example, promoting participation in the labor market and strengthening the human capital of low-income groups) may prevent the rise in economic disparities.

\footnotetext{
${ }^{24}$ These indications are also in line with findings from recent research on Latin America (the most unequal region in the world), where the recent decline in inequality appears to be mostly related to labor income developments (Lustig, Lopez Calva, and Ortiz-Juares 2015).
} 


\section{Annex 1. Gini Coefficients, Pseudo-Gini (or Concentration) Indexes, and Gini Correlations}

The Gini coefficient for income $y$ can be written as:

$$
\begin{aligned}
& G_{y}=\frac{2 \operatorname{cov}(y, F(y))}{\bar{y}} \\
& \text { or } \\
& \operatorname{cov}(y, F(y))=\frac{\bar{y} G_{y}}{2} .
\end{aligned}
$$

The Gini index captures the distance of the observed income distribution from a hypothetical condition of perfect equality in which each individual would be endowed with exactly the same income (in such a case, the Gini index would be equal to zero). ${ }^{25}$

If income $y$ comes from $K$ sources, the Gini index can be decomposed as follows (Lerman and Yitzhaki 1985; CBO 2011):

$$
\begin{aligned}
& G_{y}=\sum_{k=1}^{K} \underbrace{\left[\frac{\operatorname{cov}\left(y_{k}, F(y)\right)}{\operatorname{cov}\left(y_{k}, F\left(y_{k}\right)\right)}\right]}_{\text {pseudo-Gini (or concentration) index for income component } k} \underbrace{\left[\begin{array}{c}
\text { component } k \text { 's share } \\
\text { of total income }
\end{array}\right.}_{\begin{array}{c}
\text { Gini index for income } \\
\text { component } k
\end{array}}
\end{aligned}
$$

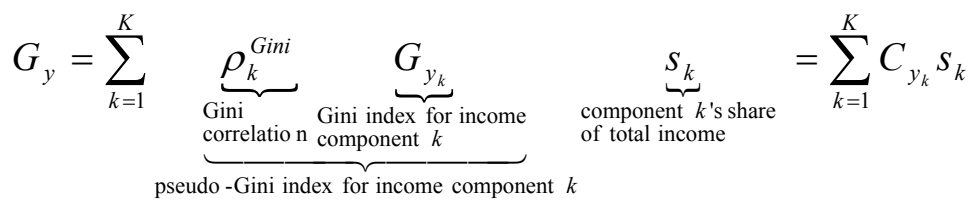

in which the pseudo-Gini (or concentration) index is given by equation (10):

$$
C_{y_{k}}=\rho_{k}^{\text {Gini }} G_{y_{k}}=\frac{2 \operatorname{cov}\left(y_{k}, F(y)\right)}{\bar{y}_{k}}
$$

and the Gini correlation index is given by equation (11):

$$
\rho_{k}^{\text {Gini }}=\frac{\operatorname{cov}\left(y_{k}, F(y)\right)}{\operatorname{cov}\left(y_{k}, F\left(y_{k}\right)\right)}=\frac{2 \operatorname{cov}\left(y_{k}, F(y)\right)}{\bar{y}_{k} G_{y_{k}}} .
$$

As equation (9) indicates, the Gini index is a weighted average of the pseudo-Gini indices of income components, and the weights are the income shares. But what is the difference

\footnotetext{
${ }^{25}$ A Gini index equal to 1 would be observed in the case of extreme inequality in which one individual would appropriate all available income, leaving nothing to the others.
} 
between a Gini and a pseudo-Gini index for an income component $y_{k}$ ? As can be seen by comparing equations (6) and (10), the difference is due to the reference ranking of individuals used in the two calculations. For the pseudo-Gini index $C_{y_{k}}$, the weights attached to each individual correspond to the ranking in the distribution of total income $(F(y))$, whereas for the Gini index $G_{y_{k}}$, the reference ranking would be that of the distribution of the $k$ th income component $\left(F\left(y_{k}\right)\right)$. The two indices would be the same if the ranking of individuals in the two distributions were the same, that is, if no reranking would take place when moving from the income component distribution to the total income distribution. It should also be noted that the higher an income component share (of total income) is, the lower the possibility of reranking (and therefore the closer $C_{y_{k}}$ and $G_{y_{k}}$ would be) (Pyatt, Chen, and Fei 1980).

The decomposition of the Gini index presented here has been used in many empirical studies. We use the Gini index as a measure of inequality because it is the inequality measure most widely used both in the literature and in policy analysis. The literature has shown, however, that the classical Gini decomposition suffers some limitations. In particular, Shorrocks (1982, 1983) shows that there is no unique way to decompose inequality, and proposes an alternative decomposition rule that satisfies a set of desirable properties ${ }^{26}$ and delivers contributions for each income component to inequality, which are not anchored to the use of a specific measure. The decomposition proposed by Shorrocks is in equation (12):

$$
S H_{k}=\frac{\operatorname{cov}\left(y_{k}, y\right)}{\operatorname{var}(y)} .
$$

In the framework set forth in this paper, the contributions to inequality of each income component are instead given by equation (13):

$$
S H_{k}^{G}=\frac{\operatorname{cov}\left(y_{k}, F(y)\right)}{\operatorname{cov}(y, F(y))} .
$$

The standard Gini decomposition in the analysis presented in this paper is appropriate for several reasons. First, in this analysis, the standard Gini decomposition and the Shorrocks measure provide very similar results. ${ }^{27}$ Second, because market income is decomposed into

\footnotetext{
${ }^{26}$ For example, symmetry (meaning that the order of the income components does not affect the decomposition results) and continuity (which requires that for each income component the results do not depend on the number of other income components).

${ }^{27}$ If we consider the four countries whose results are summarized in Table 1, the standard Gini decomposition and the Shorrocks measure provide very similar assessments of the contribution of each income component to
} 
only two exhaustive components (see Annex 2), the Gini decomposition is unique (Shorrocks 1982). Finally, as also highlighted by Lerman and Yitzhaki (1985), this approach provides an economic interpretation of the empirical results and the marginal effects of changes in the income sources (wage and capital shares) and their distributional characteristics (pseudo-Gini indices) can be derived.

inequality. In particular, for the observed period for the United States, the average contribution of labor income to inequality is 0.94 ( 0.6 for capital income) using the standard Gini decomposition; the corresponding Shorrocks measure $(\mathrm{SH})$ is $0.92(0.8)$. For the United Kingdom, the corresponding average values are $\mathrm{SH}_{1}{ }_{1}=$ $0.97\left(\mathrm{SH}_{\mathrm{c}}^{\mathrm{G}}=0.03\right)$ and $\mathrm{SH}_{1}=0.95\left(\mathrm{SH}_{\mathrm{c}}=0.05\right)$; for France: $\mathrm{SH}_{1}=0.96\left(\mathrm{SH}_{\mathrm{c}}^{\mathrm{G}}=0.04\right)$ and $\mathrm{SH}_{1}=0.94$ $\left(\mathrm{SH}_{\mathrm{c}}=0.06\right)$; and for Germany: $\mathrm{SH}_{1}^{\mathrm{G}}=0.94\left(\mathrm{SH}_{\mathrm{c}}^{\mathrm{G}}=0.06\right)$ and $\mathrm{SH}_{1}=0.83\left(\mathrm{SH}_{\mathrm{c}}=0.17\right)$.

The results therefore confirm that the largest impact on inequality is to be expected from labor income variations. 


\section{Annex 2. Inequality Decomposition Using the LIS Data Set}

Bringing equations (1) and (2) to the LIS data implies singling out the empirical counterparts of total income and of income components. The reference unit in the calculations in this paper is the household, and the income definition is the per capita equivalent income computed using the LIS equivalence scale. ${ }^{28}$ The countries considered in the analysis are reported in Annex Table 2.1.

Total gross income $y$ is defined as market income $m$ plus transfers $g$ :

$$
y=m+g
$$

Transfer income $g$ comprises both private transfers (such as alimony, remittances, transfers from nonprofit institutions) and public transfers (such as pensions, unemployment benefits, disability benefits). Public transfers make up the bulk of transfer income.

Gross market income $m$ is the sum of labor $^{29} l$ and capital income $c$ (from financial or nonfinancial types of investments):

$$
m=l+c
$$

Net (or disposable) household income is obtained by subtracting taxes $t$ from total income:

$$
y^{\text {net }}=y-t
$$

Using equation (9), the breakdown of changes in inequality in market income over a certain period can be obtained as in equation (17):

$$
\Delta G_{m}=\underbrace{\left[\Delta s_{l} C_{l}^{0}+\Delta s_{c} C_{c}^{0}\right]}_{\text {income shares impact }}+\underbrace{\left[s_{l}^{0} \Delta C_{l}+s_{c}^{0} \Delta C_{c}\right]}_{\text {concentration indices impact }}+\underbrace{\left[\Delta s_{l} \Delta C_{l}+\Delta s_{c} \Delta C_{c}\right]}_{\approx 0}
$$

in which $s l$ and $s_{c}$, and $C_{l}$, and $C_{c}$ are, respectively, the income shares and pseudo-Gini indices for $l$ and $c$, and 0 is the base year (or the initial year in the analysis, which varies depending on the country).

\footnotetext{
${ }^{28}$ The LIS equivalence scale is defined as the square root of the number of individuals in the household.

${ }^{29}$ The labor income definition we use includes both wages from paid employment and income from self employment.
} 


\author{
Annex Table 2.1. Countries Included in the Analysis \\ List of countries considered \\ (and indication if income components are recorded gross or net of taxes; \\ definition may vary by year of survey, in this case both gross, net or mixed are listed): \\ Australia (gross) \\ Austria (net; gross) \\ 1981; 1985; 1989; 1995; 2001; 2003; 2008; 2010 \\ Belgium (net; gross) \\ 1994; 1997; 2000; 2004 \\ Brazil (gross) \\ 1985; 1988; 1992; 1995; 1997; 2000 \\ Canada (gross) \\ China (gross) \\ Colombia (gross) \\ 2006; 2009; 2011 \\ 1981; 1987; 1991; 1994; 1997; 1998; 2000; 2004; 2007; 2010 \\ 2002 \\ 2004; 2007; 2010 \\ Czech Republic (gross) \\ 1992; 1996; 2004 \\ Denmark (gross) \\ Egypt (net) \\ 1987; 1992; 1995; 2000; 2004; 2007; 2010 \\ 2012 \\ Estonia (mixed, gross) \\ 2000; 2004; 2007; 2010 \\ Finland (mixed, gross) \\ 1987; 1991; 1995; 2000; 2004; 2007; 2010 \\ France (mixed; gross) \\ 1978; 1984; 1989; 1994; 2000; 2005; 2010 \\ Germany (gross) \\ $1978 ; 1981 ; 1983 ; 1984 ; 1989 ;$ 1994; 2000; 2004; 2007; 2010 \\ Greece (net; gross) \\ Guatemala (gross) \\ 1995; 2000; 2004; 2007; 2010 \\ 2006 \\ Hungary (net) \\ Iceland (gross) \\ India (net) \\ 1991; 1994; 1999; 2005; 2007; 2009; 2012 \\ 2004; 2007; 2010 \\ 2004 \\ Ireland (gross; net) \\ 1987; 1994; 1995; 1996; 2000; 2004; 2007; 2010 \\ Israel (gross) \\ 1979; 1986; 1992; 1997; 2001; 2005; 2007; 2010 \\ Italy (net; mixed) \\ 1986; 1987; 1989; 1991; 1993; 1995; 1998; 2000; 2004; 2008; 2010 \\ Japan (gross) \\ Luxembourg (net; gross) \\ 2008 \\ 1985; 1991; 1994; 1997; 2000; 2004; 2007; 2010 \\ Mexico (net) \\ Netherlands (gross) \\ Norway (gross) \\ Peru (net) \\ 1984; 1989; 1992; 1994; 1996; 1998; 2000; 2002; 2004; 2008; 2010 \\ 1983; 1987; 1990; 1993; 1999; 2004; 2007; 2010 \\ 1979; 1986; 1991; 1995; 2000; 2004; 2007; 2010 \\ 2004 \\ Poland (net; mixed; gross) \\ 1992; 1995; 1999; 2004; 2007; 2010 \\ Romania (gross) \\ 1995; 1997 \\ Russia (net) \\ 2000; 2004; 2007; 2010 \\ Serbia (net) \\ 2006; 2010; 2013 \\ Slovak Republic (gross; net) \\ 1992; 1996; 2004; 2007; 2010 \\ 1997; 1999; 2004; 2007; 2010 \\ 2008; 2010 \\ 2006 \\ 1980; 1985; 1990; 1995; 2000; 2004; 2007; 2010 \\ 1981; 1987; 1992; 1995; 2000; 2005 \\ 1982; 1992; 2000; 2002; 2004 \\ 1981; 1986; 1991; 1995; 1997; 2000; 2005; 2007; 2010 \\ 1979; 1986; 1991; 1995; 1994; 1999; 2004; 2007; 2010 \\ 1979; 1986; 1991; 1994; 1997; 2000; 2004; 2007; 2010; 2013 \\ 2004 \\ Uruguay (net) \\ Source: LIS database. Cut off date for data February 24, 2015. \\ Note: for a detailed definition of the recording method (gross, net or mixed) of taxes \\ see http://www.lisdatacenter.org/
}


Given that income shares add up to 1 , it follows that $\Delta s_{c}=-\Delta s_{l}$ (changes in the labor share are absorbed by an opposite change in the capital share), so that equation (17) can be rewritten as in equation (18):

$$
\Delta G_{m}=\underbrace{\Delta s_{l}\left[C_{l}^{0}-C_{c}^{0}\right]}_{\text {income shares impact }}+\underbrace{\left[s_{l}^{0} \Delta C_{l}+s_{c}^{0} \Delta C_{c}\right]}_{\text {concentra tion indices impact }}+\Delta s_{l}[\underbrace{\left[\Delta C_{l}-\Delta C_{c}\right]}_{\approx 0}
$$

and the observed impact of changes in income composition on inequality will depend on the initial values of the pseudo-Gini indices for labor and capital.

The impact of transfers and taxation on inequality can be measured by equations (19) and (20), respectively:

$$
\begin{aligned}
& \Delta G_{y}-\Delta G_{m} \\
& \Delta G_{y^{n e t}}-\Delta G_{y}
\end{aligned}
$$

Marginal effects on income inequality can be calculated from the following equation for the Gini index for gross market income:

$$
G_{m}=C_{l} s_{l}+C_{c} s_{c}
$$

Remembering that

$$
s_{c}=1-s_{l}
$$

we have that at any point in time the marginal impact from a variation in market-income composition is expressed by equation (23):

$$
\frac{\delta G_{m}}{\delta s_{l}}=C_{l}-C_{c}
$$

If the pseudo-Gini index for capital is higher than that for labor, then an increase (reduction) in the labor share reduces (raises) inequality. When considering Gini indices of the income components, this requires that

$$
G_{c}>\frac{\rho_{l}^{\text {Gini }}}{\rho_{c}^{\text {Gini }}} G_{l}
$$

which implies that the Gini index for capital has to be "sufficiently" larger than the Gini index for labor. 
The condition in equation (24) can also be written in terms of average labor and capital incomes:

$$
\bar{l}>\frac{\operatorname{cov}(l, F(m))}{\operatorname{cov}(c, F(m))} \bar{c}
$$

which requires average labor income to be "sufficiently" higher than average capital income. 


\section{Annex 3. Description of the Database}

Annex Table 3.1 reports the earliest and latest value for the Gini index for the countries included in the estimation sample.

The data sources for the estimation analysis are the following:

- For the disposable Gini index (a discontinuous variable observed only in some years, which vary depending on the country) data from various sources are used with the aim of covering the largest possible sample. The sources are the OECD, Eurostat, the World Bank's World Development Indicators, LIS, and the Socio-Economic Database for Latin America and the Caribbean.

- For the wage share, the main data source is the ILO database. When available the adjusted wage share is used. For many countries longer time series for wage shares are also published in the European Commission's Annual Macroeconomic Database (AMECO). For these countries the two datasets display similar patterns, and AMECO data can be used to extrapolate developments over a longer time period.

- The unemployment rate is taken from the IMF World Economic Outlook.

- The employment rate in the services sector comes from the ILO.

- For the variables capturing the wage setting setup we use the Institutional Characteristics of Trade Unions, Wage Setting, State Intervention and Social Pacts data set, 1960-2011 (produced by Jelle Visser, Amsterdam Institute for Advanced Labour Studies). The variables used (ictwss_Coord and ictwss_Type) capture the following aspects: coordination of wage-setting, and the type, or the modality or mechanism through which coordination of wage-bargaining behavior is produced. The higher the value of the variable the higher the degree of coordination or centralization of the wage-bargaining framework.

- The dispersion of labor income is measured as the ratio of total income of the top 10 percent to the bottom 10 percent, and data are taken from the World Bank's World Development Indicators.

- The ratios of public revenue, social protection spending, and health expenditures to GDP are taken from the IMF World Economic Outlook; Eurostat; OECD; the World Health Organization; the United Nations Educational, Scientific and Cultural Organization; CEPALSTAT; the Asian Development Bank; the World Bank; and the IMF International Financial Statistics. 
- Economic globalization is measured as a score based on actual flows and trade restrictions, and the data are drawn from the KOF Index of Globalization (Dreher, Gaston, and Martens 2008).

- Financial globalization is proxied by the log of total foreign assets and liabilities divided by GDP, which is computed from data from updated and extended versions of the data set constructed by Lane and Milesi-Ferretti (2007).

Annex Table 3.1. Countries Considered in the Estimation and Descriptive Statistics for Inequality

\begin{tabular}{|c|c|c|c|c|c|}
\hline \multirow[b]{2}{*}{ Country } & & \multicolumn{2}{|c|}{ Earliest Observation } & \multicolumn{2}{|c|}{ Latest Observation } \\
\hline & & Gini & Year & Gini & Year \\
\hline Argentina & EME & 0.46 & 1995 & 0.44 & 2007 \\
\hline Armenia & EME & 0.34 & 2003 & 0.31 & 2008 \\
\hline Australia & ADV & 0.28 & 1981 & 0.34 & 2008 \\
\hline Austria & ADV & 0.23 & 1987 & 0.27 & 2011 \\
\hline Azerbaijan & EME & 0.35 & 1995 & 0.34 & 2008 \\
\hline Belarus & EME & 0.29 & 1995 & 0.27 & 2008 \\
\hline Belgium & ADV & 0.23 & 1985 & 0.24 & 2011 \\
\hline Bhutan & LIDC & 0.47 & 2003 & 0.38 & 2007 \\
\hline Bolivia & LIDC & 0.56 & 1997 & 0.44 & 2009 \\
\hline Bosnia and Herzegovina & EME & 0.36 & 2007 & 0.36 & 2007 \\
\hline Brazil & EME & 0.55 & 2004 & 0.52 & 2008 \\
\hline Bulgaria & EME & 0.31 & 1995 & 0.26 & 2012 \\
\hline Burkina Faso & LIDC & 0.40 & 2003 & 0.40 & 2003 \\
\hline Burundi & LIDC & 0.33 & 2006 & 0.33 & 2006 \\
\hline Cameroon & LIDC & 0.41 & 1996 & 0.40 & 2001 \\
\hline Canada & ADV & 0.32 & 1971 & 0.32 & 2008 \\
\hline Chile & EME & 0.54 & 1996 & 0.51 & 2009 \\
\hline China & EME & 0.36 & 1996 & 0.42 & 2005 \\
\hline Colombia & EME & 0.55 & 2000 & 0.53 & 2009 \\
\hline Costa Rica & EME & 0.43 & 1995 & 0.49 & 2009 \\
\hline Côte d'Ivoire & LIDC & 0.37 & 1995 & 0.44 & 1998 \\
\hline Croatia & EME & 0.27 & 1998 & 0.37 & 2011 \\
\hline Cyprus & ADV & 0.29 & 1997 & 0.31 & 2012 \\
\hline Czech Republic & ADV & 0.26 & 1996 & 0.27 & 2004 \\
\hline Denmark & ADV & 0.26 & 1987 & 0.27 & 2012 \\
\hline Dominican Republic & EME & 0.46 & 1996 & 0.46 & 1996 \\
\hline Egypt & EME & 0.30 & 1996 & 0.31 & 2008 \\
\hline Estonia & ADV & 0.36 & 2000 & 0.30 & 2012 \\
\hline Finland & ADV & 0.21 & 1987 & 0.26 & 2012 \\
\hline France & ADV & 0.29 & 1979 & 0.31 & 2012 \\
\hline
\end{tabular}




\begin{tabular}{|c|c|c|c|c|c|}
\hline Gabon & EME & 0.41 & 2005 & 0.41 & 2005 \\
\hline Georgia & EME & 0.40 & 2003 & 0.41 & 2008 \\
\hline Germany & ADV & 0.27 & 1973 & 0.28 & 2012 \\
\hline Greece & ADV & 0.35 & 1995 & 0.35 & 2012 \\
\hline Guatemala & EME & 0.56 & 2002 & 0.53 & 2006 \\
\hline Honduras & LIDC & 0.52 & 2001 & 0.58 & 2005 \\
\hline Hong Kong SAR & ADV & 0.43 & 1996 & 0.43 & 1996 \\
\hline Hungary & EME & 0.29 & 1999 & 0.28 & 2012 \\
\hline India & EME & 0.33 & 2005 & 0.33 & 2005 \\
\hline Iran & EME & 0.44 & 1998 & 0.38 & 2005 \\
\hline Ireland & ADV & 0.33 & 1987 & 0.30 & 2011 \\
\hline Israel & ADV & 0.34 & 1997 & 0.36 & 2008 \\
\hline Italy & ADV & 0.31 & 1986 & 0.34 & 2012 \\
\hline Japan & ADV & 0.30 & 1985 & 0.33 & 2008 \\
\hline Jordan & EME & 0.36 & 1997 & 0.34 & 2008 \\
\hline Kazakhstan & EME & 0.35 & 1996 & 0.29 & 2009 \\
\hline Kenya & LIDC & 0.43 & 1997 & 0.48 & 2005 \\
\hline Korea & ADV & 0.31 & 2006 & 0.31 & 2006 \\
\hline Kyrgyz Republic & LIDC & 0.36 & 1998 & 0.36 & 2009 \\
\hline Latvia & ADV & 0.27 & 1993 & 0.35 & 2012 \\
\hline Lesotho & LIDC & 0.53 & 2003 & 0.53 & 2003 \\
\hline Lithuania & EME & 0.34 & 1993 & 0.36 & 2012 \\
\hline Luxembourg & ADV & 0.24 & 1985 & 0.28 & 2012 \\
\hline Macedonia, FYR & EME & 0.28 & 1998 & 0.43 & 2009 \\
\hline Malta & ADV & 0.30 & 2000 & 0.27 & 2012 \\
\hline Mexico & EME & 0.52 & 1996 & 0.45 & 2010 \\
\hline Moldova & LIDC & 0.37 & 1997 & 0.33 & 2010 \\
\hline Mongolia & LIDC & 0.33 & 2002 & 0.37 & 2008 \\
\hline Morocco & EME & 0.39 & 1999 & 0.41 & 2007 \\
\hline Mozambique & LIDC & 0.47 & 2003 & 0.46 & 2008 \\
\hline Namibia & EME & 0.64 & 2004 & 0.64 & 2004 \\
\hline Nepal & LIDC & 0.44 & 2003 & 0.33 & 2010 \\
\hline Netherlands & ADV & 0.25 & 1983 & 0.22 & 2012 \\
\hline New Zealand & ADV & 0.32 & 1990 & 0.33 & 2008 \\
\hline Niger & LIDC & 0.44 & 2005 & 0.35 & 2008 \\
\hline Nigeria & LIDC & 0.43 & 2004 & 0.43 & 2004 \\
\hline Norway & ADV & 0.22 & 1979 & 0.23 & 2012 \\
\hline Panama & EME & 0.55 & 1997 & 0.50 & 2008 \\
\hline Papua New Guinea & LIDC & 0.51 & 1996 & 0.51 & 1996 \\
\hline Philippines & EME & 0.46 & 1997 & 0.43 & 2009 \\
\hline Poland & EME & 0.26 & 1992 & 0.32 & 2004 \\
\hline Portugal & ADV & 0.35 & 1975 & 0.34 & 2012 \\
\hline Romania & EME & 0.28 & 1995 & 0.28 & 1997 \\
\hline
\end{tabular}




\begin{tabular}{|ll|ll|ll} 
Senegal & LIDC & 0.41 & 2001 & 0.39 & 2005 \\
Serbia & EME & 0.33 & 2002 & 0.28 & 2009 \\
Sierra Leone & LIDC & 0.43 & 2003 & 0.43 & 2003 \\
Singapore & ADV & 0.42 & 1998 & 0.42 & 1998 \\
Slovak Republic & ADV & 0.25 & 1996 & 0.26 & 2012 \\
Slovenia & ADV & 0.23 & 1997 & 0.23 & 2004 \\
South Africa & EME & 0.57 & 1995 & 0.63 & 2009 \\
Spain & ADV & 0.32 & 1980 & 0.34 & 2012 \\
Sri Lanka & EME & 0.41 & 2002 & 0.40 & 2007 \\
Sweden & ADV & 0.26 & 1967 & 0.25 & 2011 \\
Switzerland & ADV & 0.31 & 1992 & 0.27 & 2012 \\
Tajikistan & LIDC & 0.33 & 2003 & 0.33 & 2007 \\
Tanzania & LIDC & 0.35 & 2000 & 0.38 & 2007 \\
Tunisia & EME & 0.41 & 2000 & 0.41 & 2005 \\
Turkey & EME & 0.42 & 1994 & 0.39 & 2008 \\
Ukraine & EME & 0.39 & 1995 & 0.26 & 2009 \\
United Kingdom & ADV & 0.27 & 1969 & 0.36 & 2011 \\
United States & ADV & 0.32 & 1974 & 0.37 & 2010 \\
Uruguay & EME & 0.42 & 1998 & 0.44 & 2005 \\
Venezuela & EME & 0.46 & 1997 & 0.39 & 2007 \\
\hline
\end{tabular}

Sources: See text of this annex.

Note: $A D V$ = advanced economy; EME = emerging market economy; LIDC = low-income and developing countries. 


\section{References}

Adler, M., and K. D. Schmid. 2012. "Factor Shares and Income Inequality: Empirical Evidence from Germany 2002-2008." University of Tuebingen Working Paper No. 34, University of Tuebingen.

Alvaredo, F., A. B. Atkinson, T. Piketty, and E. Saez. 2013. "The Top 1 Percent in International and Historical Perspective." Journal of Economic Perspectives 27 (3): $3-20$.

Atkinson, A. B. 2009. "Factor Shares: the Principal Problem of Political Economy?" Oxford Review of Economic Policy 25 (1): 3-16.

Bentolila, S., and G. Saint Paul. 2003. "Explaining Movements in the Labor Share." Contributions to Macroeconomics 3 (1): 1-31.

Bruno, M., and J. Sachs. 1985. The Economics of Worldwide Stagflation. Cambridge, Massachusetts: Harvard University Press.

Checci, D., and C. García-Peñalosa. 2010. "Labour Market Institutions and the Personal Distribution of Income in the OECD.” Economica 77 (37): 413-50.

Congressional Budget Office (CBO). 2011. "Trends in the Distribution of Household Income Between 1979 and 2007.” CBO Study Pub. No. 4031, Congress of the United States, Washington.

De Serres, A., S. Scarpetta, and C. Maisonneuve. 2002. "Sectoral Shifts in Europe and the United States: How They Affect Aggregate Labor Shares and the Properties of Wage Equations." OECD Economics Department Working Paper No. 326, OECD, Paris.

Dew-Becker, I., and R. J. Gordon. 2005. "Where Did the Productivity Growth Go? Inflation Dynamics and the Distribution of Income." Brookings Papers on Economic Activity 36 (2): 67-127.

Dreher, A., N. Gaston, and P. Martens. 2008. Measuring Globalisation - Gauging Its Consequences. (Updated KOF Index of Globalization). New York: Springer Science and Business Media.

Eichengreen, B. 2007. The European Economy since 1945. Princeton, New Jersey: Princeton University Press.

Ellis, L., and K. Smith. 2007. "The Global Upward Trend in the Profit Share.” Working Paper No. 231, Bank for International Settlements, Basel.

Elsby, M. W., B. Hobjin, and A. Sahin. 2013. "The Decline of the US Labor Share." Brookings Papers on Economic Activity 47 (2): 1-63.

European Commission. 2007. "The Labour Income Share in the European Union.” In Employment in Europe. European Commission Directorate-General for Employment, Social Affairs and Equal Opportunities.

Feldstein, M.. 2008. "Did Wages Reflect Growth in Productivity?” Journal of Policy Modeling 30 (4): 591-94. 
Glyn, A. 2009. "Functional Distribution and Inequality." In Oxford Handbook of Economic Inequality, edited by W. Salverda, B. Nolan, and T. M. Smeeding. Oxford: Oxford University Press.

- and R. Sutcliffe. 1972. British Capitalism, Workers and the Profits Squeeze. Harmondworth: Penguin Books.

Goldfarb, R. S., and T. C. Leonard. 2005. "Inequality of What among Whom? Rival Conceptions of Distribution in the 20th Century." Research in the History of Economic Thought and Methodology 23: 75-118.

Gollin, D. 2002. “Getting Income Shares Right.” Journal of Political Economy 110 (2): 45874.

Gomme, P., and P. Rupert. 2004. "Measuring Labor's Share of Income.” Federal Reserve Bank of Cleveland, Policy Discussion Paper No. 7.

Harris, E., and F. Sammartino. 2011. "Trends in the Distribution of Household Income between 1979 and 2007." Congressional Budget Office, Washington.

Hoeller, P., I. Joumard, M. Pisu, and D. Bloch. 2012. "Less Income Inequality and More Growth-Are They Compatible? Part 1. Mapping Income Inequality Across the OECD.” OECD Working Paper No. 924, Paris.

International Labour Organization (ILO). 2011. "The Labour Share of Income: Determinants and Potential Contribution to Exiting the Financial Crisis." In World of Work Report 2011: Making Markets Work for Jobs. Geneva: ILO.

- 2012. Global Wage Report 2012/13: Wages and Equitable Growth. Geneva: ILO.

_. 2015. Global Wage Report 2014/15: Wage and Income Inequality. Geneva: ILO.

International Monetary Fund (IMF). 2007. World Economic Outlook. Washington, April.

_. 2014. "Fiscal Policy and Income Inequality." IMF Board Paper, International Monetary Fund, Washington.

Jacobson, M., and F. Occhino. 2012a. "Behind the Decline in Labor's Share of Income." Federal Reserve Bank of Cleveland.

_. 2012b. "Labor's Declining Share of Income and Rising Inequality." Federal Reserve Bank of Cleveland.

Jaumotte, F., and C. Osorio Buitron. Forthcoming. "Union Power and Inequality." IMF Staff Discussion Note, International Monetary Fund, Washington.

Kaldor, N.. 1961. "Capital Accumulation and Economic Growth." In The Theory of Capital, edited by F. A. Lutz and D. C. Hague. New York: St. Martins Press; London: Macmillan.

Karabarbounis, L., and B. Neiman. 2014. "The Global Decline of the Labor Share." Quarterly Journal of Economics 29 (1): 61-103.

Lane, P. R., and G. M. Milesi-Ferretti. 2007. "The External Wealth of Nations Mark II: Revised and Extended Estimates of Foreign Assets and Liabilities, 1970-2004." Journal of International Economics 73 (November): 223-50. 
Lerman, R. I., and S. Yitzhaki. 1985. "Income Inequality Effects by Income Source: A New Approach and Applications to the United States." Review of Economics and Statistics 67: $151-56$.

Lustig, N., L. F. Lopez Calva, and E. Ortiz-Juares. 2015. "Deconstructing the Decline in Inequality in Latin America." In Proceedings of IEA Roundtable on Shared Prosperity and Growth, edited by K. Basu and J. Stiglitz. New York: PalgraveMacmillan.

Luxembourg Income Study (LIS) Database, http://www.lisdatacenter.org (multiple countries; computations on microdata completed by February 24, 2015). Luxembourg: LIS.

Lydall, H. F. 1968. The Structure of Earnings. Oxford: Clarendon Press.

Mankiw, N. G. 2007. Macroeconomics, 6th edition. New York, Worth.

Marchal, J., and B. Ducros. 1968. The Distribution of National Income. London: Macmillan.

Organisation for Economic Co-operation and Development (OECD). 2008. Growing Unequal? Income Distribution and Poverty in OECD Countries. Paris: OECD.

Piketty, T.. 2014. Capital in the Twenty-First Century. Cambridge, Massachusetts: Harvard University Press.

Pyatt, G., C. N. Chen, and J. Fei. 1980. "The Distribution of Income by Factor Components." Quarterly Journal of Economics 95 (3): 451-73.

Rotondaro, V.. 2014. "Wall Street Is Worried about Inequality?" National Catholic Reporter website, October 14. http://ncronline.org/blogs/ncr-today/wall-street-worried-aboutinequality.

Shorrocks, A. F. 1982. "Inequality Decomposition by Factor Components." Econometrica 50 (1): 193-211.

- 1983. "The Impact of Income Components on the Distribution of Family Incomes." Quarterly Journal of Economics 98 (2): 311-26.

Stigler, G. 1965. "The Influence of Events and Policies on Economic Theory." Essays in the History of Economics. Chicago: University of Chicago Press.

Stockhammer, E. 2013. "Why Have Wage Shares Fallen? A Panel Analysis of the Determinants of Functional Income Distribution." ILO Working Paper No. 470913, International Labour Organization, Geneva. 